\title{
FORM AFTER URBANISM: THE POTENTIAL OF GROSSFORM
}

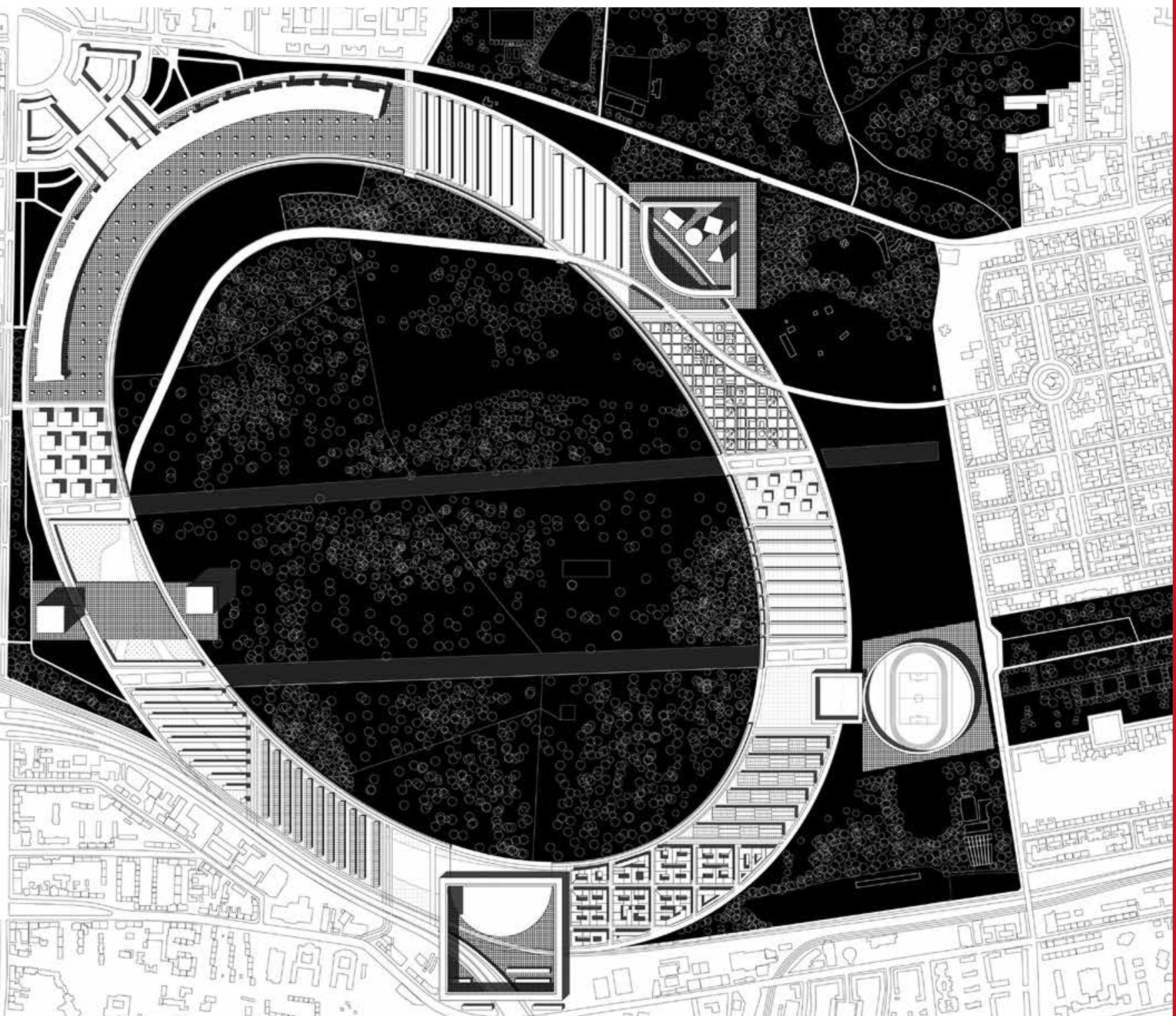


ABSTRACT - Grossformen im Wohnungsbau is the title of an unassuming pamphlet that German architect O.M. Ungers published in 1966 as part of the Veröffentlichungen zur Architektur series (VzA \#5) during his tenure at the TU Berlin in the 1960's. In it Ungers reimagines the singular architectural intervention at a scale between architecture and urbanism as a counter measure to the rapid urbanization brought about by Europe's postwar boom. The formal coherence of Grossform (literally meaning "large form" in German) could provide a framework within which the unplannable processes of the contemporary city played out, while acting as stable markers of identity in an expanding urban field of increasing formlessness. Many of the ideas introduced in Grossformen would resurface throughout Ungers' career, and eventually find their way into the better known Green Archipelago project. But where the morphologically pure islands in the Green Archipelago form a "dialectic city" only as a federation of ideal fragments, the scaleless concept of Grossform equally suggests the possibility of the island itself becoming a "dialectic object," containing the exacerbated differences of the archipelago within. Faced with an urban environment in which traditional tools of urbanism have come to be swept away irrevocably by a limitless proliferation of building production, this reconsideration of the urban agency at the architectural scale appears highly pertinent today. Reconstituting the conceptual underpinnings of Grossform and outlining the trajectories of the "dialectic city" and "dialectic object" in reference to Ungers' work, this paper aims to contribute to the (re) emergent debate on the conditions and constitutions of the architectural object: Through the combination of programmatic neutrality and formal specificity, Grossform may serve as the starting point for a contemporary paradigm in which the architectural object carries renewed urban relevance beyond its bounded form.

Keywords: archipelago cty, form, monumentality, O.M. Ungers, urbanism

"This century has been a losing battle with the issue of quantity."

Thus announced Rem Koolhaas the death of urbanism 20 years ago and predicted an era concerned with fields, processes, expanding boundaries and flows. This prognosis has proven remarkably accurate, and the last 20 years have been testament to a search for a renewed urban agency through the "informal" and "soft" and a manipulation of processes and infrastructures. Albeit drastically exacerbated since the 1990 s by globalization and digitalization, the formal disintegration of cities is by no means a new phenomenon. Already by the mid 1960s the essential outlines of this process were visible enough for architects to prompt increased speculation on alternative models of urban thinking that went beyond both the historical city and CIAM's ageing functionalist doctrine and sought to engage with the new challenges. 


\section{BETWEEN FORM AND INFRASTRUCTURE}

Among this first generation, groups such as Team 10 had since the 1950s developed an expanded understanding of architecture that would incorporate infrastructures, embrace notions of flexibility and states of "in-between-ness", and value relationship over finite form. It was through contact with the work of Alison and Peter Smithson, Aldo van Eyck and other core members of this group that the young German architect Oswald Mathias Ungers first started to developed a lifelong interest in urbanism - and it would be in contrast to the ideas of Team 10 that he sharpened his own conceptual framework, increasingly becoming estranged from the group in the 1970's. Grossformen im Wohnungsbau was published as VzA \#5 in December 1966, the year after Ungers had attended the 1965 Team 10 meeting in Berlin (which he documented as issue \#3 of his newly launched Veröffentlichungen zur Architektur pamphlet series). Based on a lecture given in Moscow earlier that year, Grossformen stands out among other VzA pamphlets in that it is Ungers' first attempt to formulate a coherent position for architectural action in response to the very "battle with the issue of quantity." ${ }^{2}$ Acutely aware of the problem at hand, Grossformen would draw somewhat different conclusions. On the opening pages a small drawing illustrates a thought experiment: If the eight million living units built between 1950 and 1965 were given architectural form, they would cover the $500 \mathrm{~km}$ of highway between Hamburg and Frankfurt in a building 100 stories tall. This image sets up a unique and - at the time - uncommon position for the relationship between architecture and infrastructure: While comparable in scale of production and volume, Ungers does not equate them: The central question for him is how an increase of quantity can be transformed into a new architectural quality. This new quality is for Ungers inextricably connected to a new way of thinking architectural form: Grossform is to be the architectural response to the scalar jump of infrastructures caused by mass production, population growth, and increased mobility. This response, although literally translating as "large form", is less about size but about formal coherence. Consequently Ungers defines Grossform through four formal categories:

“...

1. The existence of an over-accentuated element

2. The existence of an additional binding element

3. The existence of a figure and theme

4. The existence of a system or an ordering principle“ 3

Form in Grossform acts as a stabilizer and container within which program and infrastructure play out. Ungers proceeds to lay out four basic categories of Grossform: "Street," "Plateau," "Wall," and "Tower." While the latter two are described as formal, and show an interest in considerations of type, the first two categories are labelled "functional". An extensive catalogue of precedents illustrates each category, assembling projects by pre- and 
postwar modern architects (including Le Corbusier, the Smithsons, van den Broek \& Bakema, Atelier 5 in addition to several of his own projects) and covers the scalar range between building (Torre Velasca by BBPR) and city (Linear City by B. Lavrov). Interestingly, there is little conceptual difference between form and function for Ungers: "Street" and "Plateau" as "continuous linear element" and "expansive ordering element" with the quality to "bind disparate parts." ${ }^{4}$ - take elements typically considered in infrastructural terms and idealize them as abstract types. This "containment" of infrastructure within formal categories is remarkably different from the systems- and performance-based approach that characterized the work of many of Ungers' contemporaries, but also his own thinking for much of the 1960s. ${ }^{5}$ Where much of the architectural thinking of the time focused on the manipulation of infrastructures and systems to directly impact human behavior in a habitat no longer defined by traditional elements of architecture, Grossform assumes no direct correlation in this regard. Infrastructure is treated as formal element and decoupled from any notion of determinism. At the same time formal concerns for Ungers do not exist in a vacuum and removed from human experience. It is through its formal legibility that architecture (and by extension, infrastructure) assumes a unique position among its surroundings and can be understood conceptual act rather than functional necessity.

\section{GROSSFORM AS “THEME”}

Koolhaas' own response to the "losing battle with the issue of quantity" 6 is to abandon both the pursuit of form and urbanism altogether and define "Bigness" as an interior condition between a building's façade and core. For him, sheer size alone - in conjunction with the potential of content suffices to create a condition of interior multiplicity, where "such a mass can no longer be controlled by a singular architectural gesture, or even by any combination of architectural gestures." ${ }^{7}$ Ungers' by contrast is explicit about absolute size not being the exclusive qualifying criteria for Grossform. For him a small house can be a Grossform, "as much as a block, a district or an entire city." ${ }^{8}$ Adalberto Libera's Casa Malaparte is included as an example of a Grossform, in which the entire design is determined by the overaccentuated elements of stair and plateau. The formal coherence achieved by "the existence of a figure or a theme" ${ }^{9}$ - is thus more important than "gross - large", which refers less to absolute size but to the inclusive quality associated with strong form. Where Bigness rebuts the desire for a large building's exterior to truthfully express content (understood by Koolhaas as program), Ungers introduces a different kind of formal legibility as a quality through which Grossform supersedes the sum of its parts: "Only when a new quality arises beyond the sum of individual parts and a higher stage of development is reached, Grossform emerges." ${ }^{10}$

No less than Bigness, Grossform consequently de-couples form and 
content. But where for Koolhaas program alone is a sufficient organizing device, the "new quality" for Ungers emerges from what he calls architectural "themes": "Concepts such as living wall, living carpet, living funnel, living hill and living panel contain larger connections and the same time characterize categories of a new approach to imagination in design." 11

This metaphorical legibility - architecture as "Wall", "Funnel," or "Carpet" - is by no means a self-serving tool, but intended to establish architecture as separate from the performative and managerial aspects of the city. As scaleless ideal form, the "theme" sets apart Grossform from what Pier Vittorio Aureli would later call the "sea" of "urbanization" 12 - the expansive agglomeration of a predominantly infrastructurally driven built environment. The cognitive process of "reading" architecture- less in an analogy to language but as a fundamental visual act - allows the architectural intervention to become a charged presence in the city by directly appealing to the observer's capability for conceptual synthesis. The parts thus become subservient to the idea of the whole. The idea of the theme was a recurring topic in Ungers' thinking throughout the 1970s and '80s and would be elaborated upon particularly in his contribution to the "MANtransFORMS" exhibition at the Cooper-Hewitt Museum in New York in 1976 and the associated publication City Metaphors. ${ }^{13}$ It may be with some difficulty that from today's point of view - having experienced various degrees and qualities of postmodern "thematic" narratives - the idea of the theme can be appreciated in its initial ambition. One of the most lucid accounts of this intent may be a passage from Ungers' 1982 book Die Thematisierung der Architektur (Architecture as Theme):

"The need for a thematization of architecture means nothing if not moving away from the blind alley of pure functionalism or - at the other end of the spectrum - from stylistic aberrations and a return to the essential content of architectural language." 14 "An architecture that does not derive its themes from itself is like a painting that tries to be nothing more than a photographic reproduction. The theme and content of architecture can only be architecture itself." 15

\section{BETWEEN ARCHITECTURE AND THE CITY}

Grossform marks the beginning of a move away from a systemic thinking about the city that characterized the late modern project within CIAM and equally within the following generation. Commonly, responses to the challenges of urbanization were understood in the early 1960 s as having to be embrace the entirety of the human habitat as a more or less continuous environment. By superseding distinctions between individual, building and city, concepts such as the megastructures promoted by Reyner 
Banham aimed at the integration of the entirety of human experience into a coherently plannable whole. Accordingly, much of Ungers' work on the city around the time of Grossformen was indebted to an approach that interpreted the city as a system of infrastructures into which the individual building was to be absorbed. A good example would be Ungers' Veröffentlichungen zur Architektur publication Berlin 1995 (VzA \#25, 1969) which envisions Berlin's future development as an entirely systematized and quantifiable process of urbanization. Grossformen is not entirely free from the systems thinking of the 1960's, but it starts to mark the beginning of a reorientation in Ungers' work.

When Ungers writes that "[...] every building loses its importance as a self-contained unit, [...] This leads to the interpretation of buildings as parts of different, but coherently interrelated systems." ${ }^{16}$ he adheres to a paradigm that - at least in writing - stresses the importance of a larger systemic framework. But despite this, the actual focus of Grossformen is not on systemic integration, but the singular architectural intervention. The tightening of formal relationships and architecture's core competencies of space-making for the first time hint at the potential of difference over seamless integration. The localized "qualitative determination of place." 17 Ungers envisions, speaks of the potential to leverage this degree of visible difference towards a potential to engage in a series of open-ended relationships with the city and its occupants. No longer understood as the inevitable outcome of a larger system (such as the "cell" is the inevitable consequence of "megastructure"), Grossform re-asserts architecture as an equal agent in the constellation of the city. Both "form" and "theme" start to move into the vacuum left behind by a functionalism not able to fulfill its promises. Ungers sees them as neither self-reflective nor symbolic, but as proactive tools to engage in a series of dialectic exchanges which would open up new possibilities beyond systemic determinism. Not the pure autonomous object is the goal of Grossform, but the architectural intervention in constant dialogue with the city's non-architectural systems as well as with each other.

However, Grossform stops short of either a concern with architecture's internal processes of formation or an obsession with the narrative fragment, and displays a continued belief in the agency of architecture's transformative potential. While all of this is only implicit in Grossformen at this point, Ungers would ultimately move much more radically towards breaking the coherence of the systemic integration and explore the intensified dialectics between increasingly antithetical qualities of the single intervention in the urban field.

A project that like no other marks this shift is Ungers' 1972 project for the Tiergartenviertel in Berlin: a competition entry for the development of a linear city area along the Landwehrkanal. The team around Ungers (whose most notable member was a young Rem Koolhaas ${ }^{18}$ ) faced an urban 
condition marked by various degrees of disconnect: firstly, between the official desire to develop the area in a coherent way as a future connection between West-Berlin and the historic center in the East and its de facto location as a peripheral area adjacent to the Berlin wall; secondly, between the area north of the canal with its singular volumes and the southern part with the remains of a nineteenth century block structure. The proposal consists of a series of five single interventions, each responding to and acting upon a specific urban condition: each Grossform in this constellation remains localized and episodic. Each object aggressively transforms its immediate context: a series of perimeter blocks are placed on the interior of an existing block, densifying at the same time as confronting the existing war-torn blocks with its own ideal mirror-image. A "pedestrian cross" forces a relationship between four individual sectors by spanning across the street, and finally - almost the inverse - a gridded ideal volume is itself segmented by the existing roads. All interventions appear as if suspended between the commitment to a larger whole and the dedication to their sites. They share a language of abstract abrasiveness that sets them apart from their respective contexts, yet do not quite move beyond a collection of exemplary objects towards a larger totality. While most of these islands are tied to larger systemic networks of infrastructure (the pedestrian connects to a newly proposed subway line, a sunken building frames a subway stop as a linear volume, and the gridded multipurpose building is conceived as a hub at the crossing of two roads and two subway lines), even these systems appear disconnected and unable to provide the stable background for the floating islands.

The project comments as much as it acts: the impossibility of a totalizing concept for the Tiergartenviertel is rendered visible, but the dystopian paralysis is countered with the transformative energy of each intervention. The Tiergartenviertel competition marks a definitive shift towards realizing the potential of Grossform as an integral part of the concept of the dialectic city that Ungers would lay out in subsequent years as a coherent idea. The dialectic city fully acknowledges the impossibility of contemporary urban environments to be planned according to a single strategy, instead calling for the simultaneous presence of thesis and antithesis as a system in which each Grossform takes on the character of a distinct island of exacerbated difference to its neighbors.

"The city made up of "complementary places" consists of the largest possible variety of different parts, in each of which a special urban aspect is developed with a view to the whole. In a sense it is a system of the "city within the city." Every part has its own special features, without however being complete or self-contained. [...] and therefore combines with other highly developed places to form a complex system, a kind of federation." 19

The best known manifestation of the dialectic city in Ungers' own work is likely the project for "The City in the City - Berlin as Green Archipelago." 


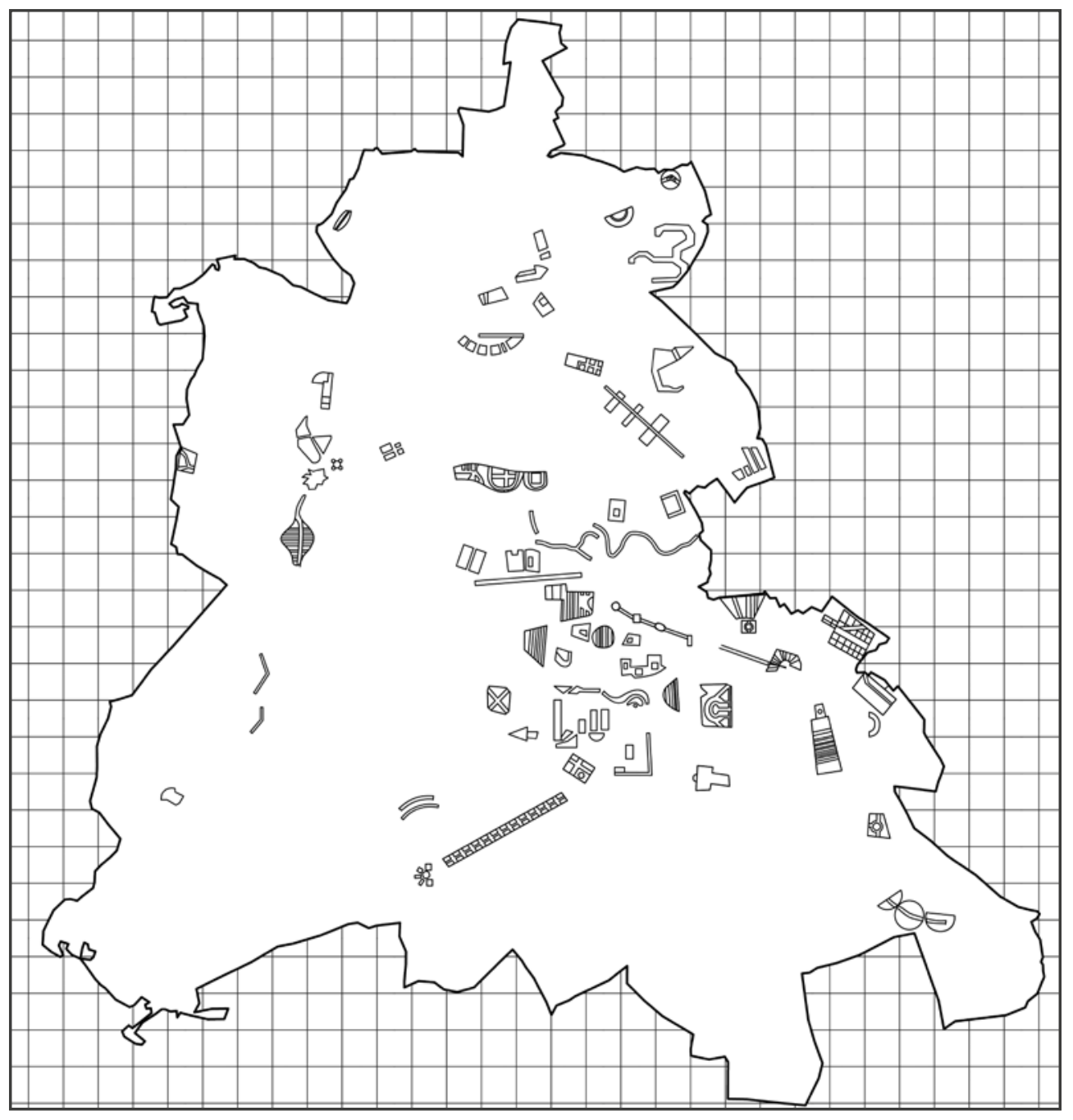

Figure 1. Where the Green Archipelago forms a federation of parts, Grossform suggest both a model for multiplicity-within-unity of each island and the reading of West-Berlin as a single "dialectic object."

The outcome of the 1977 Cornell Summer Academy - a collaboration with significant contributions by Ungers' former student Rem Koolhaas and others ${ }^{20}$ - transforms Berlin's greatest weakness into a conceptual asset: the city's lack of formal coherence is exacerbated by its reduction to a series of morphologically pure islands floating in a metropolitan void. Retroactively idealized, each island becomes a fragment of an ideal city independent from each other yet co-dependent in a federative system: Leonidov's Magnitogorsk is suspended next to the Weinbrenner's baroque plan of Karlsruhe in an urban space of exacerbated difference. Ungers refers to this quality as coincidentia oppositorum (coincidence of opposites), a term borrowed from Nicholas of Kues' De Docta Ignorantia. Emergent in the Tiergartenviertel and fully formed in the Green Archipelago the model of "variety-in-unity" is already visible as one of the ambitions central to Grossform. 


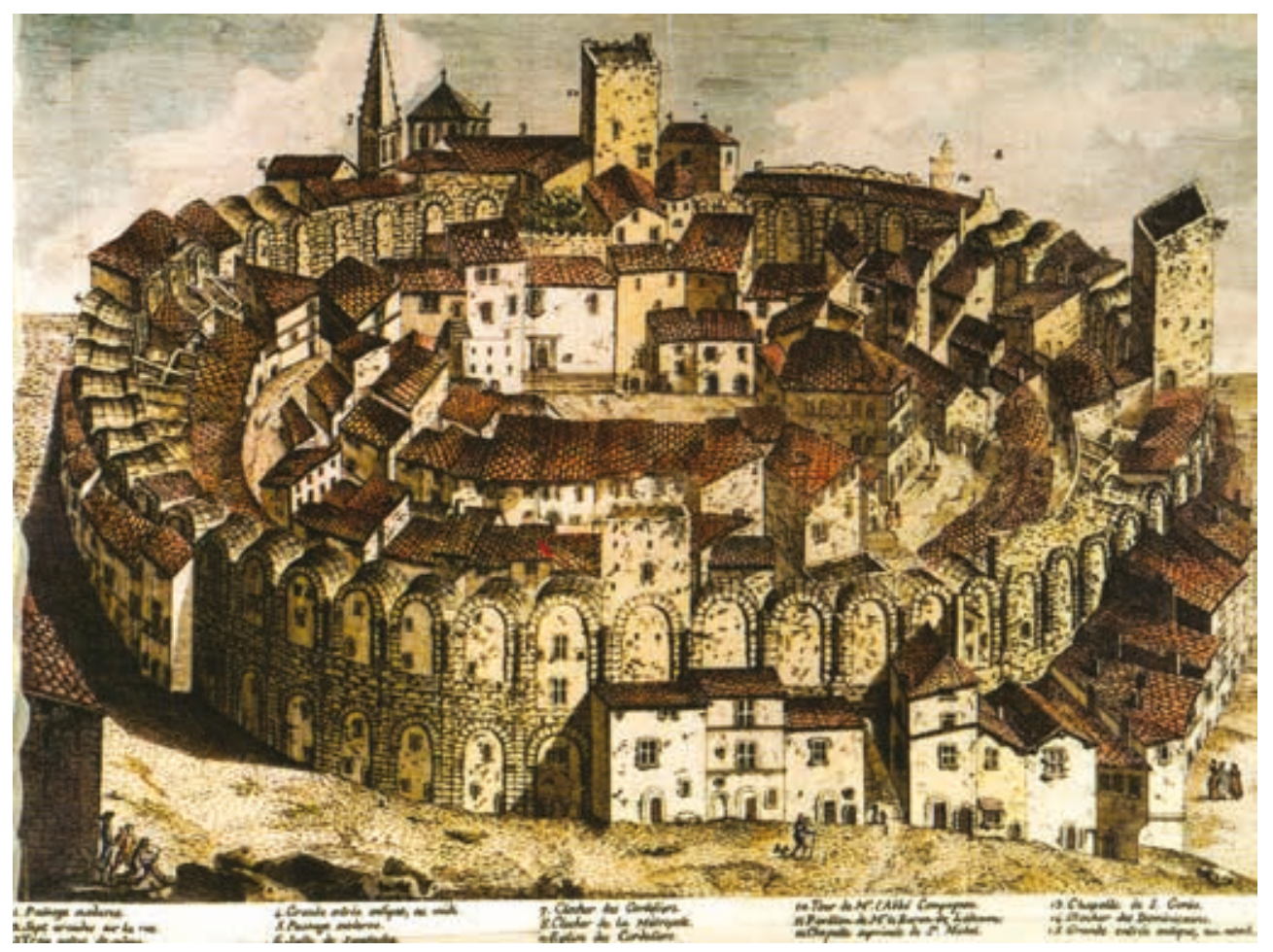

Figure 2. Historic prototype for a Grossform between "object" and "city": the medieval city of Arles (France) built into the Roman amphitheater.

\section{BETWEEN SINGULARITY AND MULTIPLICITY}

Ungers saves his most important point - the underlying thesis statement for his manifesto - for the last pages of the pamphlet when he answers the rhetorical question "Why Grossform?":

"Grossform creates the framework, the order and the planned space for an unpredictable, unplanned for, spontaneous process - for a parasitic architecture. Without this component any planning remains rigid and lifeless." 21

The capacity of the formal framework to contain a multiplicity of unpredictable contents is supported by an illustration of the medieval city of Arles occupying the fortified container of the former Roman amphitheater after the decline of the Roman Empire. This image is remarkable in two ways: Firstly, it expands on the previously mentioned separation of form and content and introduces the component of change over time: Not only can the framework of the radial structure supersede immediate considerations of function, but it can do so over time and in the most radically antithetical way - bridging even the difference between monumental architecture of imperial Rome and medieval residential fabric.

Form here is entirely disconnected from ideological content or social connotation, and for Ungers it is the architectural presence sui generis that 
enables new sets of social possibilities precisely because it can rise above programmatic prescription. Although acting as a kind of superstructure, the "flexibility" displayed in the Arles arena is very different from the one sought in the various incarnations of the megastructure approach from the 1960s. Megastructures in their majority relied on the overarching agency of systems of structure and climate control to define a habitat no longer bound by traditional elements and enclosures of architecture. ${ }^{22}$ Grossform strongly rejects the predominance of the systemic side of architecture and inverts this relationship, albeit towards a similar goal of openness and interchangeability: here the explicit emphasis is on the basic elements of spatial production and the irreducible typical forms of architecture.

"Superstructure" in Grossform is always formal structure, and systems are imaginable at best as part of the parasitic infill. Here, Grossform comes closest to some of the ideas put forth by Aldo Rossi around the same time: in The Architecture of the City (1966) he uses examples of repurposed Roman architecture (the arenas of Arles and Nîmes, the Santa Croce district of Florence and plans for the transformation of the Coliseum by Carlo Fontana and Pope Sixtus V) to support the claim for the dialectic relationship between fundamental types of the urban artifact and the dynamics of the city. Ungers' thesis on Grossform, in fact reads much as a direct analogy to Rossi's description of the Portuguese city of Vila Viçosa which he examines from a similar point of view: "Only the preexisting condition of a closed and stable form permitted continuity and the production of successive actions and forms." ${ }^{23}$

Ungers' interest in the dialectic relationships of Grossform, however, was not exclusively focused on its role in and exchange with the city, but equally invested in the inner workings of Grossform as an architectural object and self-contained entity itself: The second suggestion inherent in the Arles image is a blurring between the distinction of "object" and "fabric" - or put in another way, the possibility for Grossform to exist simultaneously as "object" and "city". With a clear boundary to the outside, all relationships (temporal/ programmatic/ideological) in Arles are relegated to the inside of a complex container and negotiated within the confines of the object and its inherent formal logic. Unlike the islands of the Tiergartenviertel in their precarious balance between fragment and whole, the whole is never in question. All parts in Arles - from the concentric arrangement of dwellings to the addition of the fortification towers - are subservient to the larger object without sacrificing their respective individual character. In an analogy to the dialectic city this quality of the object to negotiate difference within its confines will be referred to here tentatively as the "dialectic object".

Much of the reading of Ungers' work has privileged a view of an emerging postmodern urbanity based on the fragmentary character of his urban projects. Yet for Ungers "variety" and "unity" are inseparably linked in a dialectic entanglement and Grossformen equally lays the foundations for 


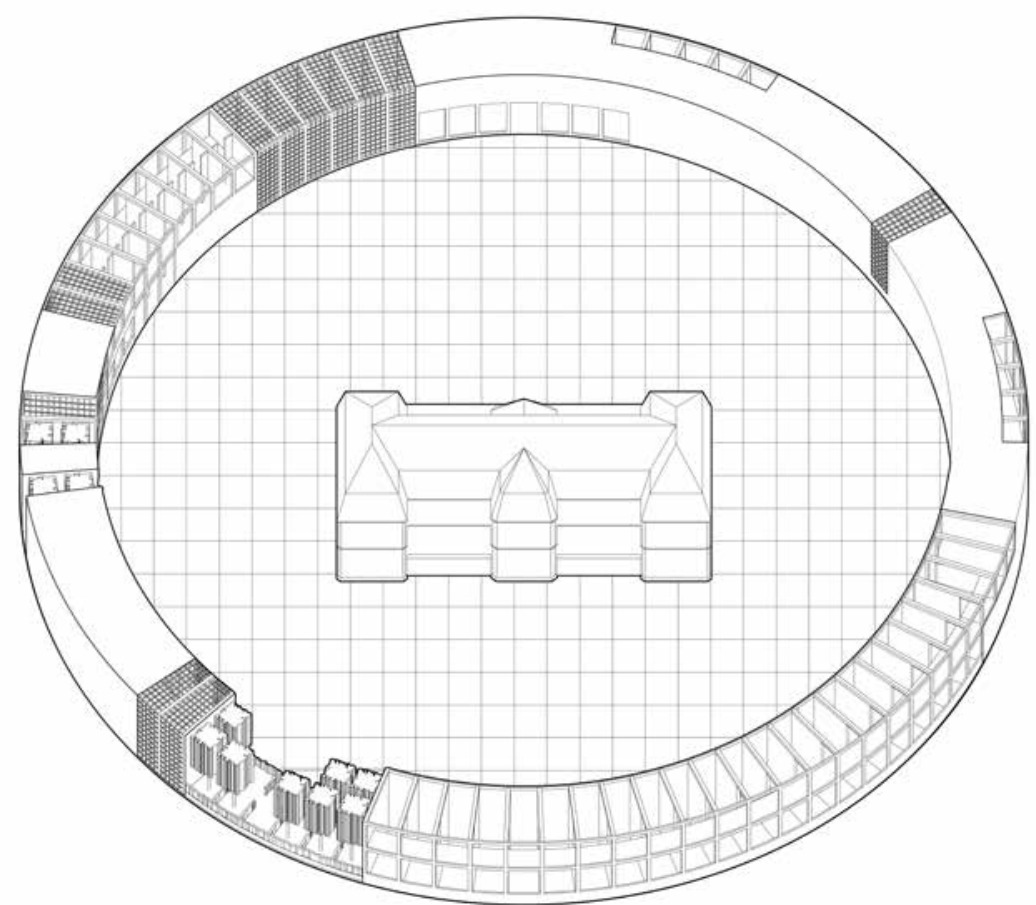

Figure 3. Dialectics within the object: The linear structure of Ungers' Morsbroich Museum subtly transforms a primary structure to contain difference.

a number of projects that start from the other end of this spectrum. One such example is the unassuming design for the expansion of the museumcastle of Morsbroich near Leverkusen of 1975. In an analogy to Arles the project consists of a thickened elliptical wall determined by its linear spatial enclosure and a radial structure of bearing walls and frames.

The internal logic is gradually subjected to a series of transformations to accommodate different programs (housing, café, art school) and a variety of spatial and sectional configurations in the segments. Morsbroich approaches the problem of coincidentia oppositorum in a way that could be described as the inverse of the logic of the Tiergartenviertel competition: where Berlin's absence of coherence prompts an overemphasis on individual dialectic islands, Morsbroich accepts the "island-ness" of the baroque museum garden, then subtly undermines its totality from the inside. Ungers explains:

"This conception of architecture is neither unitary nor pluralistic, neither closed nor open, neither rigid nor free. It is linked to a theme, on which it produces variations and the whole variety of its possibilities for expression is brought into play. It is not based on a dogmatic position or on a political programme, but on the aspiration for an architecture characterized by conceptual and thematic restraint. It is conceived to prevent the rigidity of total order and also the chaos of total independence." ${ }^{24}$ 
Tiergartenviertel and Morsbroich operate on extreme ends of the spectrum of Grossform, the former emphasizing a conceptual totality understandable only as the "theme" of urban islands (pointing the way towards the archipelago) and the latter zooming in on the possibilities of one island and its inherent potentials to contain difference within while largely disconnected from its surroundings. This set of nested dialectic relationships - between the city and the object and the object and its constituent parts - was by no means exclusive for Ungers.

An earlier project displays both of these relationships simultaneously and achieves a remarkable balance as a "not-quite-object". Cologne's Grünzug Süd was conceived between 1962-65 resulting from a competition to develop a heterogeneous area between the peripheral districts of Cologne Zollstock and Raderthal. Interestingly, Ungers describes the project as an "attempt to deduce a new order from the characteristics of both districts. This is the specific content of the project as well as the generalized one," ${ }^{25}$ positioning it fittingly as a prototypical experiment.

The design consists of the simple linear organizing principle (again, the theme of the "wall"), that spans across several blocks and reinforces the edge between Cologne's southern suburb and a large park, the actual Grünzug or greenbelt. Divided into six "thematic" segments, each is treated as a distinct enclave and finds its own organizing principle within the primary theme of the wall. The wall thus undergoes a series of morphological transformations similar in operation to Morsbroich's transformed ellipse: as double wall, folded wall, and closed perimeter block, which itself again contains objects within its poché. Each segment interprets a morphological situation found in the surrounding context: an impressive spread as part of the competition boards assembles these urban types before they are embedded as transformations into the linear primary structure. The wall-object becomes a catalyst through which contextual clues are assembled, reinforced and ultimately shape a new context in which the situation as found is "not only to be preserved, but also to be interpreted and enhanced in their historical situation." 26

What results is a "linear city" held together by a simple formal primary structure robust enough to be adopted to a variety of uses. Grünzug Süd plays out two dialectic relationships at the same time: one between the legible "wall-object" and the city, the other one between the segments within the wall. As a "not-quite-object", the project is discernible in its totality, yet simultaneously exists as a series of exchanges with the city. Each of these moments are highly transformative in their immediate contexts (and in this way resemble the agency displayed by the interventions of the Tiergarten competition) yet belong simultaneously to a conceptual totality.

Grossform provides a template for a project that is rooted equally in a disciplinary concern for architecture's core values as much as a 


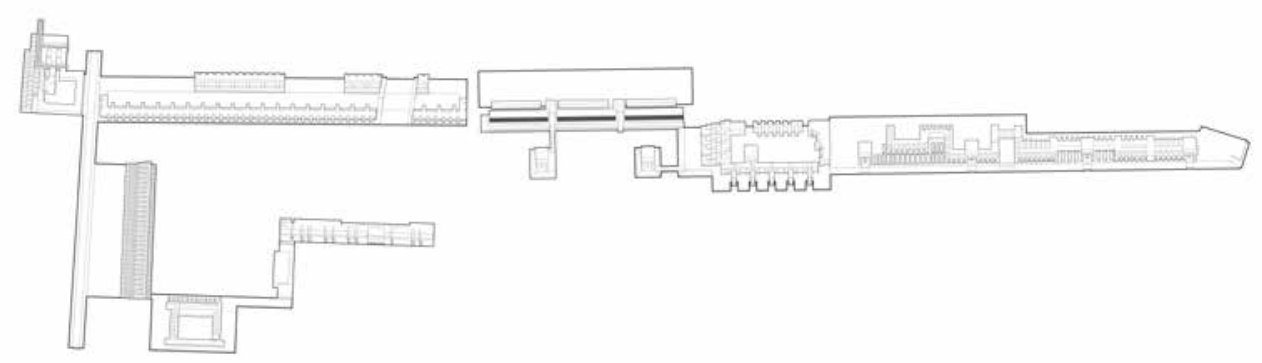

Figure 4. Grossform as “Almost-Object”: Ungers' Project for the Grünzug Süd in Cologne oscillates between part and whole.

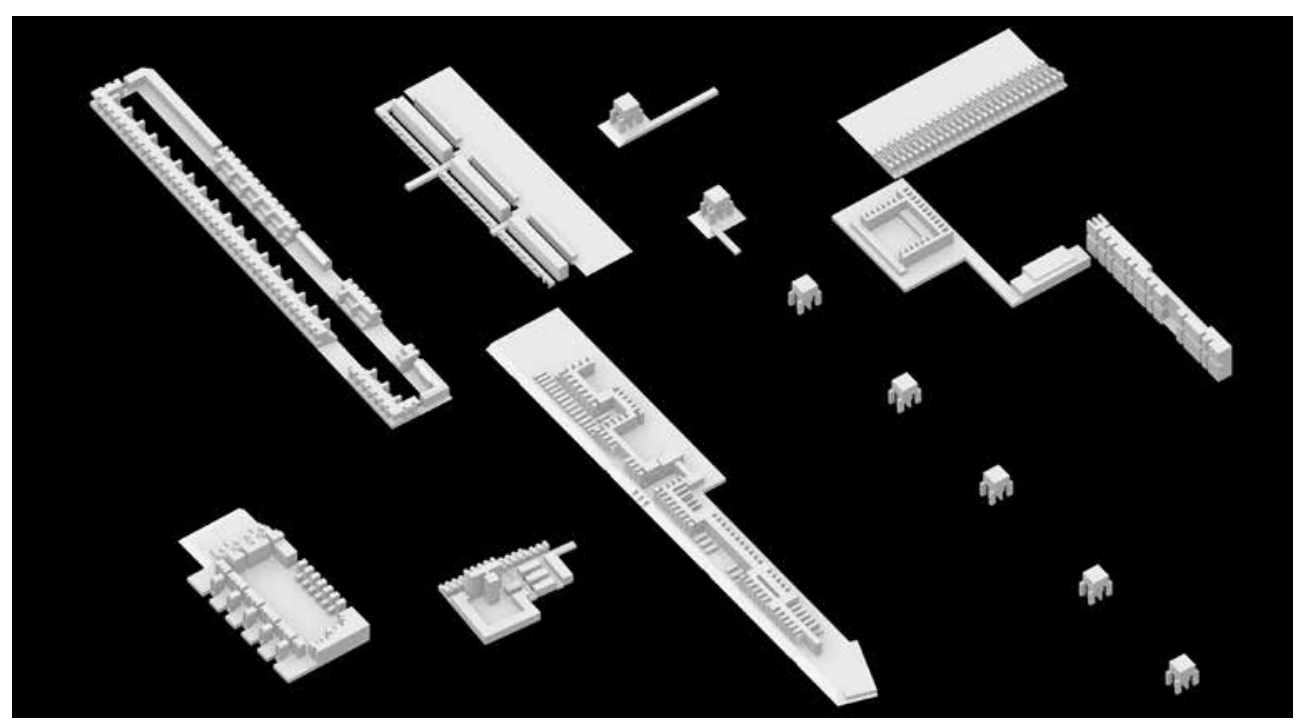

Figure 5. The parts of Grünzug Süd: an archipelago of exacerbated differences. Different groupings of dwellings are organized along the primary "theme" of the wall.

consideration of urban processes. In contrast to many of his contemporaries, however, Ungers never reduces architecture to a mere instrument to direct these processes, but acknowledges a complex set of dialectic relationships between form and social content. The distance at which he positions architecture from questions of social agency is easy to misread as a disregard for these concerns. Yet it is precisely this distance that to him represents the only possibility to carve out a space in the metropolis of the late $20^{\text {th }}$ century that remains truly open to unscripted occupation.

Grossform - and much of Ungers' work throughout the 1960s and '70s maintains a precarious balance between autonomy and contingency - often at the cost of being heavily criticized by both proponents of a "socially engaged" architecture as much as declared "formalists". As his relationship with the members of Team 10 cooled down due to his formalizing tendencies in the 1970s, Ungers would conversely find himself fiercely attacked by a frustrated Colin Rowe who had to witness his supposed formalist co-conspirator devise design studios on social housing during his tenure at Cornell University between 1969 and 1975. 


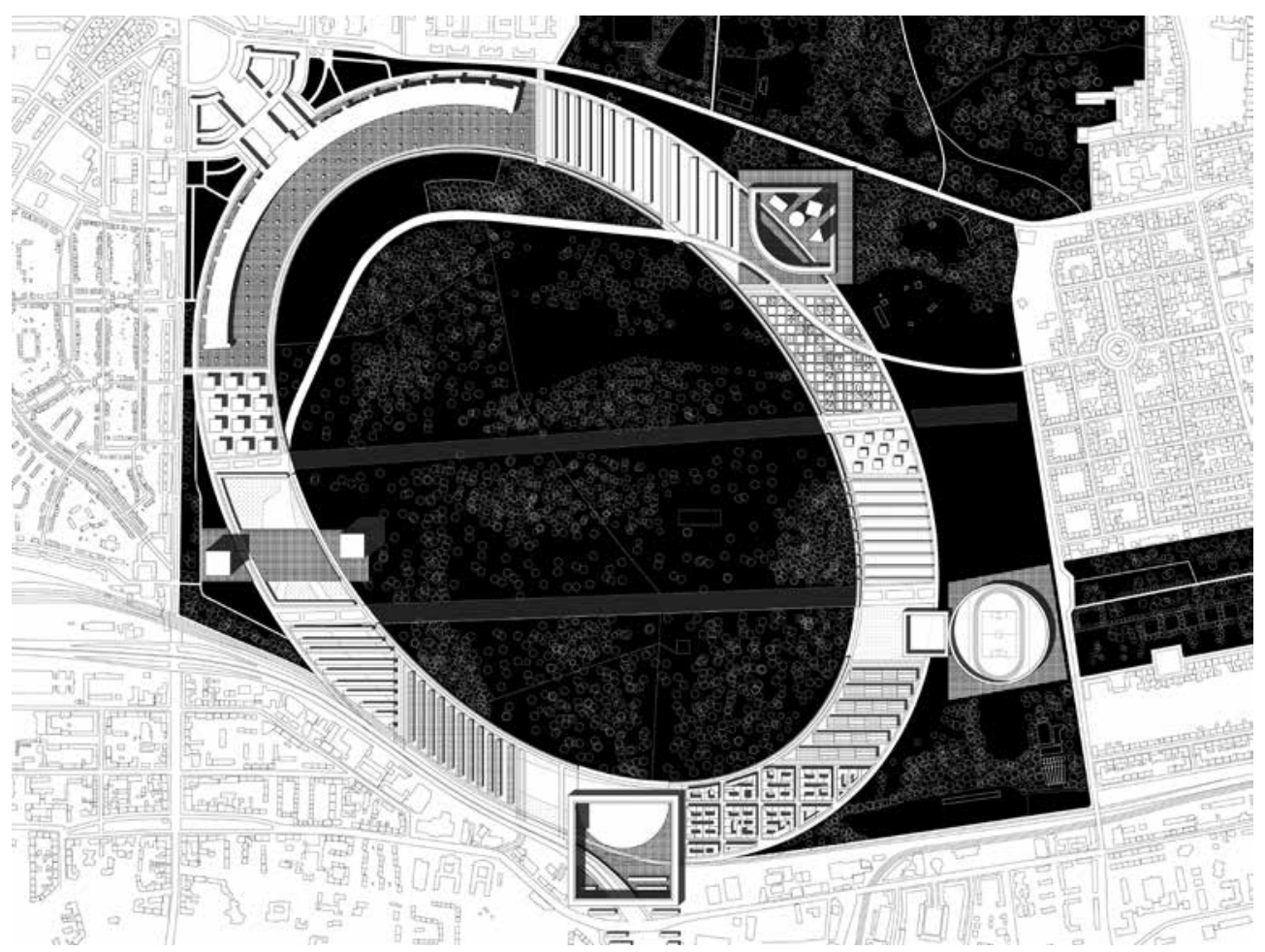

Figure 6. Martin Hättasch, Project for the Reuse of the Decomissioned Airport Berlin Tempelhof, 2015. Tempelhof's historically charged void is interpreted as an "accidental" Grossform. The functional "birth defect" of the neo-baroque plan and resulting disconnect between form and function is transformed into an asset as the formal framework for a new district. Embedded in this new city-object is a dual set of dialectic relationships: between different types of housing fabric and between monument and fabric. The resulting relationship is less one between fragments, but rather one in which different parts contribute to a legible larger whole.

Grossformen im Wohnungsbau is the attempt to formulate this "in-between" position into a coherent manifesto for architecture's agency in the city. It remains an incomplete project, and although many of its ideas can be traced throughout Ungers' work, Grossformen is much more than a historical document. In 1966, Grossform starts to grapple with the issue of quantity and a city that increasingly dissolved into a field of urbanization a process whose results Rem Koolhaas lays out unsparingly thirty years later in "Whatever Happened to Urbanism". But in many ways the essential positions have remained unchanged - with the ghosts of the 1960s haunting the discursive landscape of today.

A generation of architects has since the ' 90 s indeed ventured out on a journey to irrigate "territories with potential", enable "fields that accommodate processes", "deny boundaries", and may even have discovered some "unnameable hybrids" ${ }^{27}$ along the way. Fueled by the possibilities of digital data and motivated by additional challenges of globalization and ecological necessity, this generation has expanded on a position laid out in its fundamentals by Team 10 and others. At the same 


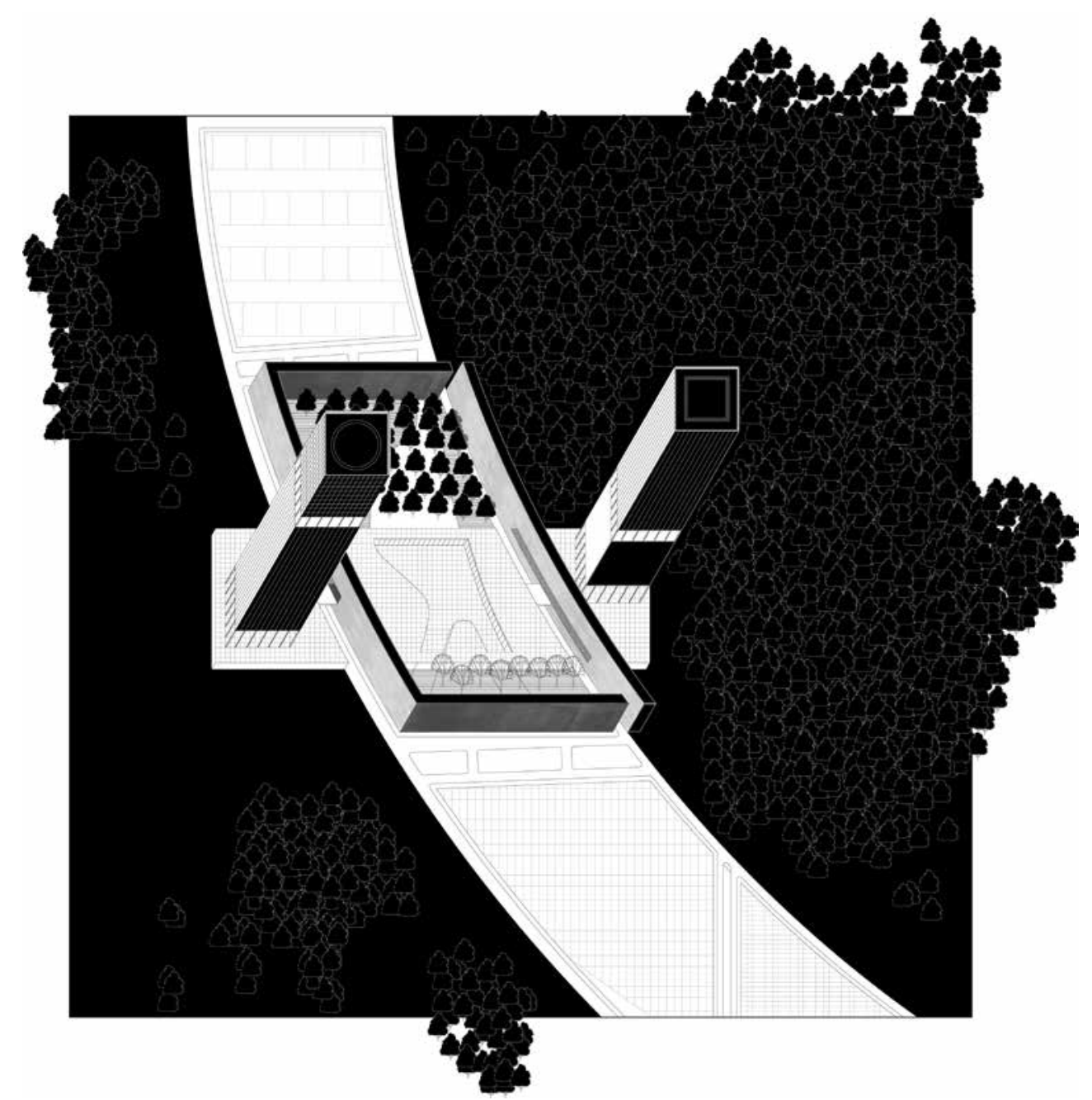

Figure 7. Martin Hättasch, Project for the Reuse of the Decomissioned Airport Berlin Tempelhof, 2015. Tempelhof's historically charged void is interpreted as an "accidental" Grossform. The functional "birth defect" of the neo-baroque plan and resulting disconnect between form and function is transformed into an asset as the formal framework for a new district. Embedded in this new city-object is a dual set of dialectic relationships: between different types of housing fabric and between monument and fabric. The resulting relationship is less one between fragments, but rather one in which different parts contribute to a legible larger whole.

time a newer generation is currently setting out to resurrect a project of formal autonomy concerned with disciplinary processes, formation, representation and the conditions of the architectural object. Owed in part to a desire for a renewed cultural significance of architectural form, this discursive trajectory finds itself at times dangerously close to a regressive stance towards a (supposed) formal autonomy turned disengagement.

Grossform can serve as a strong reminder that "object" and "city" "disciplinarity" and "engagement" - need not necessarily be mutually exclusive. The set of dialectic relationships which Grossform enables between architectural object and city, and within the architectural object 
itself - can be a starting point towards an expanded understanding of the architectural object's capacities to engage rather than retreat. In times of increasing political instabilities and economic flux it may be the formal architectural object that can once again provide a neutral backdrop and define spaces for a renewed collective experience in the vast expanses of digital and physical fabric. As Grossform recognizes, this is possible precisely because form is disconnected from the non-formal systems that make up our economic, ecological and political environment. As such the architectural object becomes not the deterministic and inevitable result of our understanding of the city, but the stable framework for what we don't control. As the plannable city crumbles away the dialectic object may starts to take on some of the tasks formerly provided by the city: frictions, opposites, programs and constituencies are increasingly being negotiated within the boundaries of the object. The process is one of simultaneously scaling up and down: the object becomes more and more like the city, the city more like an object.

\section{POSTSCRIPT}

The closing image of Grossformen im Wohnungsbau - the medieval city of Arles growing from the ruins of the Roman Empire - may contain an analogy that is equally haunting and soothing: Grossform at the center of the renaissance of the polis after urbanization has run its course and expansion reached its limits. Grossform as a new beginning. The dialectic object as new city from the ruins of the empire. 


\section{Notes}

1 Rem Koolhaas, "What Ever Happened to Urbanism," in OMA, Rem Koolhaas, and Bruce Mau, S,M,L,XL (New York: Monacelli, 1995), 959-971: 961.

2 Ibid.

3 Oswald M. Ungers, "Notes on Megaform", in Oswald M. Ungers, Erika Mühlthaler (eds.), Grossformen im Wohnungsbau, 6 - Ungers himself translates Grossform as Megaform. To avoid confusion with the same concept introduced by Kenneth Frampton ("Megaform as Urban Landscape"), the German term will be used throughout the text.

4 Oswal M. Ungers, Erika Mühlthaler (eds.), Grossformen im Wohnungsbau, not numbered.

5 See here in particular other $V z A$ pamphlets such as Berlin 1995 (VzA \#25, 1969), which continue to display a strong belief in the infrastructural and managerial side of urban planning even after the publication of Grossformen.

6 Rem Koolhaas, "What Ever Happened to Urbanism," cit., 961.

7 Rem Koolhaas, "Bigness or the Problem of Large", in OMA et al., S,M,L,XL, cit., 499.

8 Oswald M. Unger, Grossformen im Wohnungsbau, introduction, not numbered: "Kennzeichnend ist nicht die numerische Größe. Ein im Volumen kleines Haus kann ebensogut eine Grossform sein wie ein Häuserblock, ein Stadtteil oder eine ganze Stadt'. (Translation by the author.)

9 Oswald M. Ungers, "Notes on Megaform", in Grossformen im Wohnungsbau, 6.

10 Oswald M. Ungers, Grossformen im Wohnungsbau, introduction, not numbered: "Erst wenn zu der Summe von Einzelteilen eine neue Qualität hinzukommt und eine höhere Entwicklungsstufe erreicht wird, entsteht eine Grossform." (Translation by the author.)

11 Oswald M. Ungers, "The Problem of Quantity in Design"“, in Oswald M. Ungers, Erika Mühlthaler (eds.), Grossformen im Wohnungsbau, 5.

12 In his article "Toward the archipelago", LOG 11 (Anyone Corp., winter 2008) Pier Vittorio Aureli distinguishes between polis and urbs as basic concepts of cohabitation. Urbanization is defined as a largely infrastructurally driven instrument for territorial organization and expansion rooted in Roman military and colonizing operations.

13 Oswald M. Ungers, Morphologie / City Metaphors ((Cologne, Ger.: Verlag Walther König, 1982).

14 Oswald Mathias Ungers, Architettura come tema I Architecture as theme (Milan: Electa / New York: Rizzoli, 1982), 10.

15 Ibid., 9.

16 Oswald M. Unger, "Form within the City", in O.M. Ungers, Erika Mühlthaler (eds.), Grossformen im Wohnungsbau, 5.

17 Ibid., p. unmarked.

18 The similarities between the urban islands of the Tiergartenviertel and the blocks of Koolhaas, "City of the Captive Globe" have been commented upon by several authors, including André Bideau in Architektur und symbolisches Kapital: Bilderzählungen und Identitätsproduktion bei O. M. Ungers, (Bauwelt Fundamente 147 / Basel, Switz.: Birkhäuser 2011)

19 Oswald M. Ungers and S. Viehts, The Dialectic City (Milan: Skira, 1997), 20.

20 The genesis of the "Green Archipelago" has been traced in great detail in the recent critical edition by Florian Hertweck and Sébastien Marot: Florian Hertweck and Sébastien Marot (eds.), The City in the City - Berlin: A Green Archipelago (UAA Ungers Archives for Architectural Research, Zürich, Switz.: Lars Müller Publishers, 2013).

21 Oswald M. Ungers, Grossformen im Wohnungsbau, not numbered. (Translation by the author.)

22 Reyner Banham, one of the most prominent theoreticians of a (mega)structural approach, lays out this argument of the untimeliness of what he calls "monumental" space for example in his 1965 article "A Home is not a House" (Art in America \#2, 1965).

23 Aldo Rossi, The Architecture of the City (Cambridge MA, USA: MIT Press, 1982; or. ed. 1966), 88.

24 Oswald M. Ungers, Architettura come tema I Architecture as theme (Milan: Electa / New York: Rizzoli, 1982), 19.

25 Heinrich Klotz (ed.), O.M. Ungers 1951-1984 Bauten und Projekte (Braunschweig/ Wiesbaden DE, Vieweg, 1985), 77: "[...] ist der Versuch, aus der Besonderheit der 
beiden Stadtteile [...] eine neue Ordnung zu finden. Das ist der exemplarische Inhalt des Projekts und gleichzeitig der zu verallgemeinernde." (Translation by the author.)

26 Oswald M. Ungers: Architettura come tema / Architecture as theme (Milan: Electa / New York: Rizzoli, 1982), 27.

27 Rem Koolhaas: "What Ever Happened to Urbanism?", in OMA et al., cit., 969.

\section{Credits}

With the exceptions of the credits as stated below, all drawings are by the author (Martin Hättasch).

Figure 2. "The amphitheatre in the eighteenth century", postcard of engraving by J.B. Guibert, scanned by Robert Schediwy; source: wikimedia commons, distributed under CC-PD-Mark (https://upload.wikimedia.org/wikipedia/commons/0/08/ ArlesGuibert.JPG).

Figures 6 \& 7. Martin Hättasch \& OFFICE / mha.

Martin Hättasch is an architect and founder of "OFFICE mha" a design and research practice interrogating the intersection of architecture and urbanism, and the public potential of architectural form. He holds a Dipl.-Ing. Arch. degree from the Technische Universität Braunschweig and a Master's degree from Princeton University where he was a DAAD (German Academic Exchange Service) fellow. A registered architect in the Netherlands, he has worked with firms in Europe and the United States, including OMA. Hättasch is a faculty at the School of Architecture at the University of Texas at Austin. Previously, he has held academic positions at Rice University, Houston TX, and at Syracuse University, Syracuse NY. E-mail: m.haettasch@gmail.com 